\title{
ANXIETY OF FUTURE AND FINDING A JOB OF BACHELOR'S DEGREE STUDENTS
}

\begin{abstract}
The aim of the study is that Selcuk University Alaeddin Keykubat Campus Faculty of Health Sciences; Health Management Department, Social Work, and Nursing Department student's assessment and finding of future and job anxiety. The research studied to the Health Management, Social Services and Nursing Department of the Faculty of Health Sciences of Selcuk University Alaeddin Keykubat Campus within the central boundaries of Konya (April2017). The sample of the study comprised 324 people. In the study, the Future and Business Anxiety (2014) questionnaire that was revealed in 2013 was applied. The study that was descriptive, the quantitative research design was used. The data that was obtained by using face-to-face in the survey was analyzed and interpreted by SPSS 25.0 (Statistical Package for the Social Sciences) program. $36.4 \%$ of the students taking parts in the research were male and $63.6 \%$ were female. The percentage of students participating in the study was equal in proportion to the departments and had a ratio of $33.3 \%$. The distribution according to the grades was $15.4 \%$; the second grade was $16.7 \%$; the $3 \%$ grade was $33.6 \%$, and the 4 th grade was $34.3 \%$. Approximately $36.1 \%$ of the students involved in the research were of 1000 to 2500 , $40.1 \%$ of 2501 to $4000,17.3 \%$ of 4001 to $5500,4.6 \%$ of 5501 to 7000 , and $1.9 \%$ had a monthly income of $7001 \mathrm{TL}$ and above. $54.6 \%$ of the students participated in the study, $33.6 \%$ in the student houses and $11.7 \%$ in the family houses. As a result of the study, no significant difference was found between the anxiety levels of male and female students. The level of anxiety of the students of the health management department was significantly higher than that of the students in the social services and nursing department. No significant difference was found between the students' grades and their anxiety levels. No significant difference was found between the family income of the students and the level of anxiety. According to the results of the analysis, a significant difference was found between health management, social services, and nursing students' future anxiety scores. The department that is the highest level of future anxiety is the health management department.
\end{abstract}

Keywords: Anxiety, Job, Bachelor's Degree Students.

\section{LISANS ÖĞRENCILERINDE İ̧ VE GELECEK KAYGISI}

\section{Öz}

Bu çalışmada, Selçuk Üniversitesi Alaeddin Keykubat Kampüsü’nde Sağlık Bilimleri Fakültesi Sağlık Yönetimi Bölümü, Sosyal Hizmetler ve Hemşirelik bölümü öğrencilerinin gelecek ve iş kaygısının değerlendirilmesi ve tespit edilmesi amaçlanmıştır. Araştırma Konya merkez sınırları içerisinde bulunan Selçuk Üniversitesi Alaeddin Keykubat Kampüsü Sağlık Bilimleri Fakültesi Sağlık Yönetimi, Sosyal Hizmetler ve Hemşirelik bölümü öğrencilerine uygulanmıştır. Araştırmanın örneklemi 324 kişiden oluşmaktadır. Araştırmada 2013 yılında geliştirilen Gelecek ve İş Kaygısı anketi uygulanmıştır. Araştırma tanımlayıcı nitelikte olup nicel araştırma deseni kullanılmıştır. Araştırmada yüz yüze anket yöntemi kullanılarak elde edilen veriler SPSS programında analiz edilmiş ve yorumlanmıştır. Araştırmaya katılan öğrencilerin 36,4'ü erkek \%63,6'sı ise kadındır. Araştırmaya katılan öğrencilerin bölümlere göre dağımı eşit

\footnotetext{
- Selçuk Üniversitesi,Sağlık Bilimleri Fakültesi,mtyorulmaz@hotmail.com, ORCID No: 00000001-6670-165X
} 
miktarda olup $\% 33,3^{\prime} l u ̈ k$ bir orana sahiptir. Araştırmaya katılan öğrencilerin sınıflarına göre dağılımı ise 1.sınıflar \%15,4, 2.sınıflar \%16,7, 3. sınıflar \%33,6 ve 4.sınıflar \%34,3'lük orandadırlar. Araştırma kapsamındaki öğrencilerin yaklaşık \%36,1'i 1000 ile 2500, \%40,1'i 2501 ile 4000, \%17,3'ü4001 ile 5500, \%4,6'sı 5501 ile 7000 ve son olarak \%1,9'u 7001 TL ve üzeri aylık aile gelir durumuna sahiptir. Araştırmaya katılan öğrencilerin \%54,6'sı yurtta, \%33,6'sı öğrenci evinde, \%11,7'si ise aile evinde kalmaktadırlar. Araştırma sonucunda kadın ve erkek öğrencilerin kaygı düzeyleri arasında anlamlı bir fark bulunamamıştır. Sağlık yönetimi bölümü öğrencilerinin kaygı düzeyi sosyal hizmetler ve hemşirelik bölümü öğrencilerinden oldukça yüksek çıkmıştır. Araştırmaya dâhil olan öğrencilerin sınıfları ile kaygı düzeyi ortalamaları arasında anlamlı bir fark bulunamamıştır. Öğrencilerin aile gelirleri ile kaygı düzeyi arasında anlamlı bir fark bulunamamıştır. Analiz sonuçlarına göre sağlık yönetimi, sosyal hizmetler, hemşirelik bölümü öğrencilerinin gelecek kaygısı ortalamaları arasında anlamlı bir fark bulunmuştur. En fazla gelecek kaygısı düzeyine sahip olan bölüm sağlık yönetimi bölümüdür.

Anahtar Kelimeler: Kaygı, İş, Lisans Öğrencisi

\section{INTRODUCTION}

The amount of anxiety and indecision an individual experience surrounding career decisions will be influenced by a wide range of variables. The purpose of this study was to consider how individual differences and learning environment variables predicted career anxiety and indecision in undergraduate students. More specifically, we used two separate regression models to examine the effects of age, gender, and perceived control (i.e., individual differences) and year in university, participation in an orientation program, and students' intended faculty (i.e., environmental factors) on career anxiety and career indecision (Mortensen, 2014). Besides being a neurophysiological process, according to psychological learning which a process, people are try to interpret by combining the knowledge about a matter they have learned. The learnings' realization based on the medium stimulation of the organism that will not reveal the extreme excitement and anxiety, and the need and curiosity in human-being to motivate people to learn and to mature with mental and physical development in order for learning to occur. However, the learning theories that play an important role in the literature have a guiding role in observing the behavior of individuals (Sayar and Dinç, 2013). Because anxiety occurs, it is possible to say people may experience neutralizing circumstances in their learning process and make the learning process difficult. Money is only part of the story. Often, the majority of stress that job seekers incur spawns from smaller, less noticeable sources. Most causes of anxiety are not even recognizable to the person feeling low-grade waves of panic (www.forbes.com). To lessen the anxiety of the undergraduates about the forthcoming and to strengthen motivation when thrown into their occupations, the support for them should be given in the education and training process (Uysal et al., 2018).

The amount of anxiety and indecision an individual experience surrounding career decisions will be influenced by a wide range of variables (Daniels et al., 2011). Since the political, economic, economic and social circumstances that may arise are uncertain and people not able to experience every moment again, people worried 
about the future and could drag into anxiety. It is necessary to achieve a positive result by testing the opportunities and threats offered by life in a good way. Especially, young individuals have many issues about the future. Today's conditions lead to greater anxiety for young people. Students who have been studying since the age of seven consume most of their lives in a school environment. Therefore, the stress and anxiety of the students who come into the expectation of the future can meet. It is a known fact that the anxiety of the students in the last years of the university has increased. To ensure that the educated individuals in the country look at the future with hope, the development of job opportunities and realistic approaches should be provided within the framework of the employment policy. In areas related to problems of employment is a necessity permanent arrangements' made. Because of the lack of employment, it is inevitable for a youth desperate to appear in anxiety and present a negative thought to both their families and society. As educators and mentors, we often focus on helping undergraduate students make career decisions. However, there is also value in helping alleviate career anxiety and indecision, both of which impede decision-making and are not automatically resolved once a decision is made (Daniels et al., 2011). The investigations done students help to make many politics about education and training subjects. In this way feedbacks of obtained from the student, workings are extremely important to decide in terms of political, educational, and employment for all the governmental and bureaucratic levels (Genç et al., 2018).

In this study, the future and job anxiety of the students of the Health Management, Social Services and Nursing Department within the Faculty of Health Sciences at Selcuk University are emphasized.

\section{METHODS}

\subsection{The Purpose of the Research}

In this study, we aim it to determine and test the future and job anxiety of the students of Selcuk University Faculty of Health Sciences, Health Management, Social Services, and Nursing Department.

\subsection{The Importance of the Research}

It will envisage contributing to the field with current data and information got from the results on the future and work anxiety issue applied to other university students. That is not applied this study to the students of Selcuk University Faculty of Health Sciences emphasizes the importance of this research.

\subsection{Type of the Research}

This study was a cross-sectional field study and a descriptive study carried out using the quantitative research design. 


\subsection{The Universe of Research and the Sampling}

We performed the survey on the students of Faculty of Health Sciences at Konya Selcuk University. The universe of research is Health Management, Social Services and Nursing from the Departments of the Health Sciences Faculty. To calculate the sample size, the website that showed in the footnote was used (statisticssolutions.com,27.12.2018). According to this information, we studied 317 people in the population of 1796 people, with a sample of 317 people with a margin of error of $5 \%$ in the $95 \%$ confidence interval. We used a simple random sampling method in the investigation. Participation in research was on a voluntary basis.

\subsection{Data Collection Tool}

The Future and Job Anxiety Survey were used in the study. In this study, it was used the face-to-face questionnaire method to collect the data that were needed to test the defended hypotheses. The questions included in the questionnaire were tried to be determined under the objectives stated in our study, and the questions were understandable and short. Murat Kaya developed Future and Business Anxiety Questionnaire (2013). The questionnaire comprises 40 items and has six subdimensions. These dimensions are; economy, job, education, social environment, income, and expectation. According to the validity and reliability analysis of the scale, the scale was reliable and reliable. At the same time, confirmatory factor analysis performed by the researcher. We used five-point Likert for the answers of the questionnaire. For example, the answer to the phrase "I believe the economy will be better" includes five options such as "1-Strongly agree", "2-Agree", "3-Undecided", "4Disagree", "5-Strongly disagree". Researchers collected the data using the face-to-face survey technique with students of the Faculty of Health Sciences Selcuk University between 15.04.2018 and 30.04.2018.

\subsection{Limitations of the Study}

This research was conducted for carrying out at the central of Alaeddin Keykubat campus Selcuk University in Konya city. It has limitations the data collection tool used, hypotheses, and that the sample does not include the whole of the universe. Because of these infers, the results that are obtained from the research cannot be generalized to Selcuk University students.

\subsection{Data Evaluation}

As soon as the data obtained and after the surveys were transferred to the computer, researchers performed data control in the first step. The researchers did by transferring to the IBM SPSS 25.0 program for statistical analysis of the data. The researchers used those descriptive statistics, Independent samples t-test to test whether that has differences in the comparisons between the two groups, One-way analysis of variance (One-Way ANOVA) to test whether that has differences in the comparisons made in groups of over two for analyzes on the data. 


\subsection{Research Hypotheses}

The hypotheses of the research are below:

Hypothesis 1: $\mathrm{HO}=$ There is no significant relationship between the departments and the anxiety level of the students who were included in the study.

Hypothesis 2: $\mathrm{HO}=$ There is no significant relationship between the gender and the anxiety level of students who were included in the study.

Hypothesis 3: $\mathrm{HO}=$ There is no significant relationship between the grades and the anxiety level of students who were included in the study.

Hypothesis 4: $\mathrm{HO}=$ There is no significant relationship between the family income and the anxiety level of the students who were included in the study.

Hypothesis $5: \mathrm{HO}=$ There is no significant relationship between the departments and the average of the future expectation students who were included in the study.

\section{RESULTS}

\subsection{Socio-Economic and Demographic Characteristics}

Table 1 shows the socio-economic and demographic information that was obtained from 317 students taking part in the survey.

Table1.Socio-Economic and Demographic Characteristics of the Participants $(n=324)$

\begin{tabular}{|l|c|c|l|c|c|}
\hline Gender & $n$ & $\%$ & $\begin{array}{l}\text { Family Income } \\
\text { Distribution }(T L)\end{array}$ & $\mathrm{n}$ & $\%$ \\
\hline Male & 118 & 36.4 & $1.000-2.500$ & 117 & 36.1 \\
\hline Female & 206 & 63.6 & $2.501-4.000$ & 130 & 40.1 \\
\hline Age & $\mathrm{n}$ & $\%$ & $4.001-5.500$ & 56 & 17.3 \\
\hline $18-19$ & 48 & 14.8 & $5.501-7.000$ & 15 & 4.6 \\
\hline $20-21$ & 126 & 38.9 & $7.001+$ & 6 & 1.9 \\
\hline $22-23$ & 107 & 33.0 & Where you stay & $\mathrm{n}$ & $\%$ \\
\hline $24-25$ & 43 & 13.3 & Dormitory & 177 & 54.6 \\
\hline Department & $\mathrm{n}$ & $\%$ & Student House & 109 & 33.6 \\
\hline Health Management & 108 & 33.33 & Family House & 38 & 11.7 \\
\hline Social Services & 108 & 33.33 & $\begin{array}{l}\text { Your father's } \\
\text { profession }\end{array}$ & $\mathrm{n}$ & $\%$ \\
\hline Nursing & 108 & 33.33 & Military-Police & 19 & 5.9 \\
\hline Grader & $n$ & $\%$ & Not working & 5 & 1.5 \\
\hline
\end{tabular}




\begin{tabular}{|l|c|c|l|c|c|}
\hline 1st Grader & 50 & 15.4 & Farmer & 24 & 7.4 \\
\hline 2nd Grader & 54 & 16.7 & Retired & 38 & 11.7 \\
\hline 3rd Grader & 109 & 33.6 & Tradesman & 48 & 14.8 \\
\hline 4th Grader & 111 & 34.3 & Workingman & 47 & 14.5 \\
\hline $\begin{array}{l}\text { Monthly Spending of } \\
\text { Student (TL) }\end{array}$ & $n$ & $\%$ & Officer & 55 & 17 \\
\hline $100-300$ & 20 & 6.2 & Self-job & 56 & 17.3 \\
\hline $301-500$ & 109 & 33.6 & Others & 32 & 9.9 \\
\hline $501-700$ & 96 & 29.6 & $\begin{array}{l}\text { Does your mother } \\
\text { work? }\end{array}$ & $\mathrm{n}$ & $\%$ \\
\hline $701-900$ & 61 & 18.8 & Yes & 287 & 88.6 \\
\hline $901-1.100$ & 22 & 6.8 & No & 37 & 11.4 \\
\hline
\end{tabular}

As seen in Table 1, when looked at the participants in terms of gender, the ratio of women was $63.6 \%$ and the ratio of men was $36.4 \%$. The rate of women was rather high than that of men. Health management, social services, and nursing students took part at the same rate in the survey. $15.4 \%$ of the participants were in the first-grader and $34.3 \%$ were in the fourth-grader (most participation group). When the age of the respondents was $20-21$, the proportion of the participants was $38.4 \%$, which was higher than the other age groups. The age range of $24-25$ was lesser with $13.3 \%$. Within the distribution of the students' expenditures, the highest proportion was $33.6 \%$, which was the group comprised 301-500 TL (Turkish Lira), while the smallest ratio was $1100+\%$ with $4.9 \%$. This shows that a student's monthly expenditure was almost 408 Turkish Lira. The income of the participants' families was between 2501-4000 TL with $40.1 \%$. While the rate of students in dormitories was $54.6 \%$, the rate of students in the student houses was $33.6 \%$, and the rate of students in the family houses was $11.7 \%$.

According to this, most of the students taking part in the survey were students in dormitories. The participants' professions of the fathers were more self-employed at the same rate with $17.3 \%$ while the non-working rate was $1.5 \%$. The majority of the mothers of the participants were not working. The mother of 37 students, with a rate of only $11.4 \%$, was active.

\subsection{Analysis of Data}

Table 2. The Average Level of Anxiety with the Students' Department

\begin{tabular}{llllllll}
\hline Departments & $n$ & Mean & sd & $F$ & $p$ & Post Hoc
\end{tabular}




\begin{tabular}{|c|c|c|c|c|c|c|}
\hline 1.Health Management & 108 & 3.1023 & 0.34508 & \multirow{4}{*}{10.590} & \multirow{4}{*}{$0.000^{* *}$} & \multirow{4}{*}{$1>3>2$} \\
\hline 2.Social Services & 108 & 2.8854 & 0.27297 & & & \\
\hline 3.Nursing & 108 & 3.0248 & 0.41951 & & & \\
\hline Total & 324 & 3.0042 & 0.36126 & & & \\
\hline \multicolumn{7}{|c|}{${ }^{*} p<0.01$ (level of statistical significance) } \\
\hline \multicolumn{7}{|c|}{$\begin{array}{l}\text { In Table } 2 \text { according to one-way ANOVA analysis that was performed in } \\
\text { independent groups between the sections of the students included in the research and } \\
\text { the anxiety level averages; there was a significant difference between the anxiety level } \\
\text { and the average of health management, social services, and nursing departments } \\
\text { (p<0.01). It was found that the anxiety level of the students in the health management } \\
\text { department was higher than the anxiety level of the students in the social services } \\
\text { department. Therefore, hypothesis } 1 \text { was rejected. }\end{array}$} \\
\hline
\end{tabular}

Table 3. The Average Level of Anxiety with The Students' Gender

\begin{tabular}{llccccc}
\hline Level of anxiety & & $\mathrm{n}$ & Mean & $\mathrm{sd}$ & $\mathrm{F}$ & $\mathrm{p}$ \\
\hline \multirow{2}{*}{ Gender } & Male & 118 & 3.0040 & 0.39035 & \multirow{2}{*}{0.005} & \multirow{2}{*}{0.996} \\
& Female & 206 & 3.0042 & 0.34448 & & \\
\hline
\end{tabular}

In Table 3 according to Independent Samples t-test analysis that was performed in independent groups between the gender of the students and the anxiety level averages; there was no significant difference between independent groups $(p>0,05)$. Accordingly, it was observed that the anxiety levels of male and female students were almost the same. Therefore, hypothesis 2 was accepted.

Table 4. The Average Level of Anxiety with the Students' Grades

\begin{tabular}{|c|c|c|c|c|c|}
\hline Grades & $\mathrm{n}$ & Mean & sd & $F$ & $p$ \\
\hline 1st grader & 50 & 3.0865 & 0.37318 & \multirow{5}{*}{1.806} & \multirow{5}{*}{0.146} \\
\hline 2nd grader & 54 & 3.0449 & 0.32098 & & \\
\hline 3rd grader & 109 & 2.9961 & 0.37119 & & \\
\hline 4 th grader & 111 & 2.9552 & 0.36040 & & \\
\hline Total & 324 & 3.0042 & 0.36126 & & \\
\hline
\end{tabular}

In Table 4 according to one-way ANOVA analysis that was performed in independent groups between the grades of the students and the anxiety level 
averages; there was no significant difference between the grades and the anxiety level $(p>0.05)$. Therefore, hypothesis 3 was accepted.

Table 5. The Average Level of Anxiety with The Students' Family Income

\begin{tabular}{lccccc}
\hline $\begin{array}{l}\text { Family Income } \\
\text { (TL) }\end{array}$ & $\mathrm{n}$ & Mean & sd & $\mathrm{F}$ & $\mathrm{p}$ \\
\hline $1.000-2.500$ & 117 & 3.0045 & 0.37693 & & \\
$2.501-4.000$ & 130 & 2.9988 & 0.38057 & 0.035 & 0.965 \\
$4.001+$ & 77 & 3.0127 & 0.30307 & & \\
Total & 324 & 3.0042 & 0.36126 & & \\
\hline
\end{tabular}

In Table 5 according to one-way ANOVA analysis that was performed in independent groups between the family income of the students and the anxiety level averages; there was no significant difference between the family incomes and the anxiety level ( $p>0.05)$. Therefore, hypothesis 4 was accepted.

Table 6. The Average of Job Anxiety in the Future with Students' Departments

\begin{tabular}{lcccccc}
\hline Departments & $\mathrm{n}$ & Mean & $\mathrm{sd}$ & $\mathrm{F}$ & $\mathrm{p}$ & post hoc \\
\hline 1.Health Management & 108 & 4.04 & 1.159 & & & \\
2.Social Services & 108 & 2.56 & 0.970 & & & \\
3.Nursing & 108 & 2.09 & 1.124 & 94,221 & $0.000^{\star *}$ & $1>2>3$ \\
Total & 324 & 2.90 & 1.366 & & &
\end{tabular}

${ }^{\star *} p<0.01$ (level of statistical significance)

In Table 6 according to one-way ANOVA analysis performed in independent groups between the departments of the students and job anxiety averages; there was a significant difference among the health management, social services, and nursing students' scores of future job anxiety $(p<0.05)$. It found that the future anxiety level of the students in the health management department was higher than the students in the nursing and the social services department. Therefore, hypothesis 5 rejected.

\section{DISCUSSION and CONCLUSION}

Selcuk University Faculty of Health Sciences Health Management, Social Services and Nursing students to measure the future and work anxiety levels, the results of the students' concerns about the future anxiety examined in two parts. The results of demographic data and descriptive statistics in the first part; the analyzes of the scales given in the second part. 
Hypothesis 1 and Hypothesis 5 that are from the five hypotheses planned at the start point of the study were rejected. Hypothesis 2, Hypothesis 3, and Hypothesis 4 were accepted.

Most of the participants were female students. According to the results of the analysis, no significant difference was found between male and female students. However, some studies have shown that women's anxiety levels were higher than men. It was said that several factors influence this difference, such as the values and expectations that society expects from women to dominate. In a study conducted by Saraç and Şanlı-Kula (2016) in Ahi Evran University on 1160 students, the average anxiety level of female students was $44.44 ; 41.37$ of male students and the female students had a higher level of anxiety. In a study conducted by Dursun and Aytaç (2009) on 315 students in Uludağ University, the average level of female students' anxiety level was $44.24,38.83$ of male students, and female students had a higher level of future anxiety.

In our study, according to the results of the students who were included in the research and their anxiety level averages; a significant difference was observed between the anxiety level and the section averages, and it was found that the department with the highest level of anxiety was the health care department and the lowest anxiety level was the social services department. As the reason of these differences among the departments, it is possible to consider that the graduates of the health management department have limited job opportunities, the number of graduates in this department is higher and the number of jobs is less. Besides, it can be said that students in departments with a high financial return and a high level of status view less anxious and hopeful for the future, after graduation. According to the study conducted by Kurt (2007) in Eskisehir Osmangazi University Faculty of Arts and Sciences Department of Statistics, in the spring semester of the 2005-2006 academic year. It said the students, who work harder and who get more education in this direction, are looking forward to the future with hope and have none concern for the future.

No significant difference was found between grades and the level of anxiety, according to the results of the students' grades and the level of anxiety level. In the study conducted by Kaya (2013), it was found that job was the most important indicator in the expectations of the students about the future, and economic indicators were the second important indicator. Variance test analysis that was performed between the family income and anxiety levels of the students was included in the study. According to the results of the analysis, there was no significant difference between the family income and the anxiety level. In the study conducted by Saraç and Şanlı-Kula (2016), it was observed that students with low family income had more anxiety than the students with high family income. In this situation, the low family income causes the students to have fewer opportunities to realize their wishes in life.

Variance test analysis was performed between the sections of the students who was included in the study and the mean scores of job satisfaction. According to the results of the analysis, a significant difference was found between health management, 
social services, and nursing students' future anxiety scores. The department with the highest level of future anxiety was the health management department. Besides being a university graduate to have a job in the public sector in our country, also necessary to have a rank within the limited quota in Public Personnel Selection Exam. After graduation, students who are able to enter these rankings suffer financial difficulties; people who have graduated from the university by the people around but not able to work. This situation negatively affects the sense of self-confidence in students; it causes people to look pessimistic to the future. That health management department appointment is limited in our country increases the anxiety of the students. Students who spend a large part of their lives with education aim to get their work in return for their work. Students who have a great responsibility to their families also know of this. Health management department students who aim to spend their lives with no need others and become productive employees or managers useful to the society think it is very difficult to come to their desired position due to today's conditions. Although the health management department, which is shown among the professions of the future, has been graduating for many years, when we look at the statistics of our country, we see that there is very little job. In the Ministry of Health in the annexes of 'Sağlık Meslek Mensupları ile Sağıı Hizmetlerinde Çalışan Diğer Meslek Mensuplarının İş ve Görev Tanımlarına Dair Yönetmelik' of the job and job descriptions of the health manager and thousands of health management department, although the title of this title was not made to appoint the task and task this title is not included. In the study conducted by Şener, vd. (2010), the distribution of the teaching staff according to the fields of education examined, while the health administration and health institutions management fields not included as health management. In the 2008-2009 academic year, there are 16 faculty members in health administration and 17 faculty members in health institution management. According to the same study, 17 of the 33 teaching staff were female and 16 were male.

When the number of faculty members working in the department was examined; Marmara University ranks first with 22 instructors, Hacettepe University with 19 lecturers, and Okan University with 16 instructors. There was no academic workforce working in the department at Kırıkkale and Aksaray University. When all the departments have taken into consideration, an important part of the current teaching staff was included in the assistant professor. Assistant professor followed by an associate professor and research assistant. It was said that a significant part of the academic staff in the related departments was at the beginning of the academic development process.

The Faculty of Health Sciences, Department of Health Management, 1 (one) Assistant Professor, also serves as a staff member in health management faculty of Marmara University. It was said that the professionalism of a profession is proportional to the number of 'masters' in which power gaining autonomy. When we look at the event in this sense, in the health management, so far, the master or masters have not grown up in an adequate number. 
In conclusion, it is necessary to protect and support young individuals who are waiting put into business life through social policies and society. In our country where young qualified manpower is becoming more and more unemployed, it is necessary to emphasize this issue and to produce social and bureaucratic policies to solve the problem.

\section{REFERENCES}

DANIELS, LM, Stewart, TL, Stupnisky, RH, Perry, RP, LoVerso, T.(2011). Relieving Career Anxiety And İndecision: The Role Of Undergraduate Students' Perceived Control And Faculty Affiliations. Soc Psychol Educ. 14:409-426.

DURSUN, S., Aytaç, S. (2009). İşsizlik Kaygısı yazısı.Uludağ Üniversitesi İktisadi ve İdari Bilimler Fakültesi Dergisi Cilt XXVIII. 1(78):71-84.

www.forbes.com (2019). Is Anxiety Hurting Your Ability To Find A Job?.A.D.10/01/2019

GENÇ, Y., Durğun, A, Kara, H, Çakır, R. (2018). İnternet Kullanımının Üniversite Öğrencilerinin Yalnızlık Algılarına Etkileri. Akademik İncelemeler Dergisi (AID). 13

(2):301-336. DOI: 10.17550/akademikincelemeler.329440.

KAYA, M. (2013). Üniversite Öğrencilerinin Gelecek Beklentisinin Yapısal Eşitlik Modeli ve Chaid Analizi İle Belirlenmesi: Cumhuriyet Üniversitesi İ̈BF Öğrencilerine Yönelik Bir Uygulama. Yüksek Lisans Tezi. (Danışman: Ziya Gökalp Göktolga). Cumhuriyet Üniversitesi. Sivas.

KURT, G. (2007).Ridit Analizi ve Üniversite Öğrencilerinin Gelecek Kaygılarının İncelenmesi Üzerine Bir Uygulama, Eskişehir Osmangazi Üniversitesi Sosyal Bilimler Dergisi, 8(2): 193-206.

MORTENSEN, R.(2014). Anxiety, Work, and Coping. Vantage Leadership Consulting, Chicago, Illinois.

Sağlık Meslek Mensupları ile Sağlık Hizmetlerinde Çalışan Diğer Meslek Mensuplarının İş ve Görev Tanımlarına Dair Yönetmelik. Resmi Gazete Sayı:29007. 22 Mayıs 2014

SARAÇ, T., Şanlı-Kula, K. (2016). Üniversite Öğrencilerinin Gelecek Kaygısı. Mustafa Kemal Üniversitesi Sosyal Bilimler Enstitüsü Dergisi, 13(33): 233.

SAYAR, K., Dinç, M. (2013). Psikolojiye Giriş. Değerler Eğitimi Merkezi Yayınları. İstanbul.

ŞENER, E., Erdem, R., Akçakanat, T. (2010). Türkiye'de Lisans Düzeyinde Sağlık Yöneticisi Yetiştiren Kurumların Akademik ve Eğitsel Profili. Hacettepe Sağlık İdaresi Dergisi. 13(1):29-44. 
UYSAL, B., Kulakoğlu, E., Şentürk, E., Önal, A.C. (2018). Hastane Çalışanlarının Motivasyon ve Mobbing Algısı: Bir Afiliye Hastane Örneği. 2. Uluslararası 12. Ulusal Sağlık ve Hastane İdaresi Kongresi. 10-12 Ekim 2018. ss: 55-57. 